\title{
Investigation of behavioral developments of Kangal puppies using open field and barrier tests
}

\author{
Yasemin SALGIRLI DEMIRBAŞ, Bahri EMRE
}

Ankara University, Faculty of Veterinary Medicine, Department of Physiology, Ankara, Turkey.

\begin{abstract}
Summary: This study aimed to investigate behavioral developments and breed specific characteristics of Kangal puppies. To this aim, Kangal puppies ( 23 male, 17 female) were weekly exposed to the repeated open field test (OFT) and barrier test between 3 to 8 weeks after birth. It was detected that 3 weeks old Kangal puppies were able to display explorative behaviors. True thig motactic behaviors and unsteady walking were only observed when the puppies were 3 -weeks-old. When the puppies were 4 weeks old, time spent for standing and walking increased $(\mathrm{p}<0.05)$ and running behavior was first displayed. Sum of durations of passive behaviors increased in general $(p<0.05)$ and durations of escape behaviors decreased in the 2 nd part of the OFT ( $p<0.05)$ in 5 -weeks-old puppies. Five weeks old Kangal puppies also started to show success in the barrier test. Common body postures of the puppies were recorded as self confident and attendant along test weeks. These findings suggest that Kangal puppies achieved fine motor abilities such as steady walking and running at 4 weeks of age. Five weeks of age, on the other hand, seemed to be important for development of emotional memory, habituation and problem solving in Kangal puppies. Considering activity levels and body postures of the puppies in repeated OFT exposures, Kangal puppies might be classified as bold puppies according to "Shyness-Boldness" axis.

Keywords: Barrier test, behavioral development, Kangal Dog, open field test.
\end{abstract}

\section{Kangal yavrularının davranış gelişimlerinin açık alan ve bariyer testleri kullanılarak incelenmesi}

Özet: Bu çalışmada Kangal yavrularının davranış gelişimleri ve ırka özgü kişilik özelliklerinin incelenmesi amaçlandı. Mevcut çalışmada, Kangal yavrularına (23 erkek, 17 dişi), 3-8 haftalık dönemde haftalık olarak tekrarlı açık alan ve bariyer testleri uygulandı. Üç haftalık Kangal yavrularının keşif davranışlarını sergileme yetisine sahip oldukları tespit edildi. Gerçek tigmotaktik davranışlar ve sallantılı yürüme sadece yavrular 3 haftalıkken gözlemlendi. Kangal yavruları 4 haftalıkken, ayakta durma ve yürüme için harcanan süre arttı $(\mathrm{p}<0,05)$ ve koşma davranışı ilk kez sergilendi. Beş haftalık yavrularda pasif davranışlar için harcanan süre testin genelinde arttı $(\mathrm{p}<0.05)$ ve kaçma davranışları için harcanan süre OFT'nin 2. bölümünde azaldı $(\mathrm{p}<0.05)$. Ayrıca 5 haftalık Kangal yavruları, bariyer testinde başarı göstermeye başladı. Test haftaları boyunca yavruların genel olarak sergiledikleri vücut dili, kendine güvenli ve dikkatli olarak kaydedildi. Bu bulgular, Kangal yavrularının dört haftalık yaşta sallantısız yürüme ve koşma gibi ince motor becerilerini kazandığını göstermektedir. Ayrıca 5 haftalık yaşın Kangal yavrularında duygusal hafıza, alışma ve problem çözme açısından önemli olduğu görülmektedir. Tekrarlı OFT uygulamalarında yavruların aktivite seviyeleri ve vücut dilleri göz önünde bulundurulduğunda, Kangal yavruları "Utangaçlık-cesaret” eksenine göre cesur yavrular olarak sınıflandırılabilmektedir.

Anahtar sözcükler: Açık alan testi, bariyer testi, davranış gelişimi, Kangal köpeği.

\section{Introduction}

Most parts of the brain of newborn dogs are unmyelinated at birth $(24,29)$. Dog puppies undergo a gradual maturation in nervous system after birth, which also underlies their behavioral epigenesis $(8,24)$. Maturing process in nervous system is an important period for dogs since this period determines future behavioral characteristics of an individual. Although effects of genetic factors on maturation of the nervous system, behavioral developments and individual traits have been proved $(16,25)$, only a limited number of studies investigated breed specific early neurobehavioral development in $\operatorname{dogs}(11,28,29)$. Most of the data on early behavioral and social developments in dogs based on results of a long term research conducted by Scott and
Fuller (29). However, authors used only five dog breeds, i.e. cocker spaniels, basenjis, beagles, wire-haired terriers and Shetland sheep dogs in that study. Thus, generalization of the results to other dog breeds is questionable. In a recent study, Schoon and Berntsen (28) described neurological and behavioral developments in Belgian Malinois. However, much comparable data on breed specific physiological, behavioral and social developments in dogs are still needed (24).

Learning is one of the basic adaptation mechanisms in dogs. Learning capacities of dog puppies reach adult levels at 4-5 weeks old in accordance with the myelinisation process in central nervous system $(11,17$, 19). Scott and Fuller (29) reported that 4 week old puppy has problem solving abiliy since it can learn basic 
commands. They further stated that earliest age of problem solving in simple problem solving tests such as barrier test is 6 weeks old in dog puppies after vision capacity fully develops.

Barrier test is a simple problem solving test in which a barrier is used in order to separate the dog from any object the dog is motivated to reach. In order to solve the test, the dog in a novel environment had to navigate to the hidden object (29). OFT is a widely used method to evaluate emotional reactivity, activity level, explorative behavior and temperament of animals in response to a novel environment $(21,33)$. Marchei et al. (22) demonstrated that responses of a growing animal to the repeated OFT showed development of neurological, behavioural and social patterns. Furthermore, in various studies coping style of an individual was determined by using OFT $(4,22,26)$. Coping style can be defined as individual variability such as active versus passive, proactive versus reactive and shy versus bold in behavior and underlying physiology to environmental challenge (18). Various studies showed that human five factor, i.e. Big Five which includes the traits such as Extraversion, Neuroticism, Conscientiousness, Agreeableness and Openness can be applied to dogs. Moreover, broad dimensions described in dogs were largely in agreement with the Shyness-Boldness axis $(31,34)$. Koolhaas et. al. (18), on the other hand, suggested that stable traits in most animals can be determined by using two independent axes, a qualitative coping style axis and a quantitative stress reactivity axis. Accordingly, four extreme characteristics, i.e. shy, docile, panicky and bold can be described in individuals. Shy individuals is characterized by a high stress reactivity combined with reactive coping whereas bold individuals can be defined by low stress reactivity and proactive coping style. Animals having low stress reactivity with reactive coping are labeled as docile while panicky individuals show proactive coping style combined with high stress reactivity.

To our knowledge, no research to date has been conducted on measuring of behavioral developments in a specific dog breed using OFT. The aim of this study is to investigate (1) behavioral developments of Kangal puppies during the first 8 weeks after the birth; (2) to determine breed specific traits considering "ShynessBoldness" axis; and (3) to observe development of problem solving ability in those dogs. We believe that this is the first effort to evaluate behavioral developments and characteristics of Kangal dogs.

\section{Materials and Methods}

Subjects: Forty (23 male and 17 female) purebred Kangal puppies were used in this study. All puppies were diagnosed as healthy after a clinical examination.
Animals were identified according to their mother's name, birth date and sex as well as coat colour. The approval of ethical committee has been obtained for this study.

Housing: The experiment was carried out in the Implementation and Research Center of Kangal District Governorate. All puppies lived outdoors in cage environments with their mothers and had free access to water and food.

Experimental design: During the first 3 weeks after birth, days of eyes opening and the first balanced standing of the pupppies were recorded. To this aim, the animal keeper filled out a time table for each puppy during his daily visit to the cages. Each puppy was first taken to the OFT at 3 weeks of age after subjected to a startle test in which puppy's reaction to a sudden noise was tested. Puppies were only taken to the OFT, in case of opening of eyes, giving startle response to a sound and being able to stand on four legs. OFT was applied to puppies every week on the same day between 3 to 8 weeks after birth.

Each week, after OFT was completed, all puppies were subjected to the barrier test. As described by Scott and Fuller (29), target object was placed through the window to the outside of the barrier after puppy showed his/her interest in it. In case that puppy reached the target object in $30 \mathrm{sec}$ by moving around the barrier, he/she was recorded as successful. Barrier test was performed on the following week in case that puppy was not succesful in the previous week.

OFT area: The test was performed outdoor since puppies were living in outdoor cages. The arena was a hexagon box of $1.80 \mathrm{~m}$ diameter with compact foamboard walls at a height of $60 \mathrm{~cm}$. The floor was covered with a nylon sheet divided into $30 \mathrm{~cm}$ area squares. The OFT floor was cleaned with alcohol at the end of each test. A "stimulus-rich" installation was used in OFT which contained a novel object as described by Marchei et. al. (22). A toy car with remote control sound effect and movement was used as a novel object. It was placed on the floor of the OFT area close to the wall before the test.

Barrier test: A compact foamboard with a height of $90 \mathrm{~cm}$ and lenght of $180 \mathrm{~cm}$ was used as a barrier. In the middle of the barrier, a triangle window was opened through which the puppy could see the outside of the barrier. Cheese treats or pelush toy was used as a target object depending on puppy's motivation.

Behavioral data: For the OFT, each puppy was left gently on the center of the OFT area. Focal animal sampling was used as a sampling method (1). Thus, behaviour of each puppy was observed for a total of 300 s. Novel object was active during the last $60 \mathrm{~s}$ of OFT. 
During the OFT, durations and frequencies of certain behaviors were recorded for later evaluation by using a video camera (Sony Handycam ${ }^{\circledR}$ ) placed outside the arena on a $1.50 \mathrm{~m}$ high tripod. Accordingly, accumulated times spent in each behaviour were measured as duration of activities (Table 1) and a number of behaviours were measured as frequencies (Table 2) as previously described by Marchei et al. (22).
Statistical analyses: All data were analysed using SPSS 18.0 Inc. software program. Mann-Whitney U test was used in order to determine diffences between genders considering opening of eyes, the first balanced standing and results of the barrier test. Spearman rank correlation coefficient was used in order to measure relationships between data obtained in the first 3 weeks and physiological data as well as to measure relationships

Table 1. Description of behaviors observed during the OFT measured as durations.

Tablo 1. Açık alan testi sırasında gözlemlenen davranışların süre olarak ifadesi.

\begin{tabular}{|c|c|}
\hline Behavior & Description \\
\hline Walking unsteadily & Unsteady walking using all four legs while head is moving side by side \\
\hline Walking & Steady walking using all four legs \\
\hline Running & Running or jumping across the OFT area \\
\hline Sitting & Sitting back on haunches \\
\hline Lying & Lying on the floor while its haunch and belly touching the floor \\
\hline Sleeping & Puppy is in a stationary position while lying pn the floor with closed eyes \\
\hline Standing & Standing up on all four legs \\
\hline Walking and exploring walls & Walking while sniffing the walls of the OFT area \\
\hline Walking and exploring floor & Walking while sniffing the floor of the OFT area \\
\hline Resting and exploring walls & Puppy is in a stationary position (sitting, standing or crouched) and sniffing the walls \\
\hline Resting and exploring floor & Puppy is in a stationary position (sitting, standing or crouched) and sniffing the floor \\
\hline Passive exploration of NO & $\begin{array}{l}\text { Puppy is in contact with any part of the novel object, sniffing or touching it with nose, tongue or } \\
\text { front paws while sitting/standing/lying on the floor }\end{array}$ \\
\hline Passive avoidance from NO & Avoiding from NO by turning head away in a sitting/standing/lying position \\
\hline Active exploration of NO & Puppy is voluntarily approaching NO and sniffing or touching it with nose, tongue or front paws \\
\hline Active avoidance from NO & Avoiding from NO by walking/running away \\
\hline Polypne & Rapid breathing, panting \\
\hline Normal positions of ears & Ears held in normal/ resting position \\
\hline Lower positions of ears & The pinnae are flat on the head/ backwards for more than half/ turned sidewards \\
\hline Ears directed to stimuli & Each pinnae are directed to source of the stimuli \\
\hline Lower position of head & Head is held in a low position \\
\hline Upper position of head & Head is lifted up to form a wide angle with the neck \\
\hline Lower position of tail & Tail is held lower than neutral position \\
\hline Tail between legs & Tail is held between the legs \\
\hline Upper position of tail & Tail is held higher than neutral position \\
\hline Tail wagging & Wagging movements of the tail \\
\hline \multicolumn{2}{|l|}{ Trembling of head } \\
\hline \multicolumn{2}{|l|}{ Trembling of body } \\
\hline Circling & Turning 180-360 degree at one point \\
\hline Circling around test area & Turning 180-360 degree around the test area \\
\hline Play bow & Chest is lowered to the ground while rear end remains up \\
\hline Freeze & Stop moving with stiffed body posture \\
\hline Escape intents & Scratching or climbing the wall/rearing with front paws on the wall \\
\hline Others & Performing a different behaviour from the described ones \\
\hline \multicolumn{2}{|l|}{ Vocalistions } \\
\hline Whining & Long, high sound \\
\hline Yelping & Sudden, short, high sound \\
\hline Barking & Loud, rough noise \\
\hline \multicolumn{2}{|l|}{ Howling } \\
\hline Squealing & High-pitch sound \\
\hline
\end{tabular}


between data obtained in the first 3 weeks and results of the barrier test. In order to evaluate behavioural trends along time, week was considered as factor and "mother", "litter size" and "birth time" were considered as covariates in a two way repated measures ANOVA. Behaviours expressed as counts were analysed with poisson regression model. Results of statistical analysis were considered significant at $\mathrm{p}<0.05$.

\section{Results}

Measurements during the first 3 weeks after the birth: Dog puppies were only taken to the OFT in case that their eyes and ear channels were open and further that they were able to stand on their fours. Accordingly, the mean age of eyes opening was $13.62 \pm 0.12$ days from birth in Kangal puppies. The mean age of standing was

Table 2. Description of behaviors observed during the OFT measured as frequency.

Tablo 2. Açık alan testi sırasında gözlemlenen davranışların frekans olarak ifadesi.

\begin{tabular}{ll}
\hline Behavior & Tanim \\
\hline Line crossing & Crossing one of the lines drawn on the OFT floor with the front paws \\
Snout licking & Part of the tongue is moved along the upper lip \\
Yawning & Mouth is opened to apparent fullest extend \\
Lowering ears & Pinnae are moved to backwards for more than half \\
Lowering head & Head is changed to a low position \\
Lowering tail & Tail is changed to a lower position \\
Tuckling tail between legs & Tail is curled between legs \\
Lifting tail & Tail is elevated \\
Lifting front paw & One of the front paws is lifted up \\
Trembling of head & \\
Trembling of body & \\
Circling & Turning 180-360 degree at one point \\
Circling around test area & Turning 180-360 degree around the test area \\
\hline
\end{tabular}

Table 3. Mean durations of Kangal puppies for escape intents, lying, standing and passive behaviors.

Tablo 3. Kangal yavrularının kaçma davranışları, yatma ve pasif davranışlar için harcadıkları ortalama süreler.

\begin{tabular}{|c|c|c|c|c|c|}
\hline Dogs $(n=40)$ & Weeks & $\begin{array}{l}\text { Escape intents (sec) } \\
\qquad \bar{x} \pm S \bar{x}\end{array}$ & $\begin{array}{l}\text { Lying (sec) } \\
\quad \bar{x} \pm S \bar{x}\end{array}$ & $\begin{array}{l}\text { Standing (sec) } \\
\bar{x} \pm S \bar{x}\end{array}$ & $\begin{array}{c}\text { Passive behaviors (sec) } \\
\bar{x} \pm S \bar{x}\end{array}$ \\
\hline & 1 & $0.97 \pm 0.35^{\mathrm{a}}$ & $50.41 \pm 7.00^{\mathrm{a}}$ & $16.99 \pm 3.34^{\mathrm{a}}$ & $93.99 \pm 5.73^{\mathrm{a}}$ \\
\hline & 2 & $7.18 \pm 1.92^{\mathrm{b}}$ & $17.23 \pm 6.14^{b}$ & $50.93 \pm 5.86^{\mathrm{b}}$ & $99.49 \pm 7.92^{\mathrm{a}}$ \\
\hline & 3 & $22.42 \pm 4.66^{\mathrm{b}}$ & $23.88 \pm 9.08^{\mathrm{ab}}$ & $67.79 \pm 10.64^{\mathrm{b}}$ & $138.37 \pm 9.52^{\mathrm{b}}$ \\
\hline & 4 & $81.301 \pm 8.71^{\mathrm{cd}}$ & $10.18 \pm 6.37^{b}$ & $50.31 \pm 7.37^{\mathrm{b}}$ & $110.64 \pm 11.75^{\mathrm{ab}}$ \\
\hline & 5 & $82.627 \pm 8.78^{\mathrm{c}}$ & $18.79 \pm 8.46^{\mathrm{ab}}$ & $40.07 \pm 7.68^{\mathrm{ab}}$ & $106.93 \pm 8.86^{\mathrm{ab}}$ \\
\hline & 6 & $96.306 \pm 9.22^{\mathrm{d}}$ & $19.82 \pm 7.46^{\mathrm{ab}}$ & $35.77 \pm 7.12^{\mathrm{ab}}$ & $102.99 \pm 8.48^{\mathrm{ab}}$ \\
\hline \multicolumn{6}{|l|}{$P$ values } \\
\hline \multicolumn{6}{|l|}{ Main effect } \\
\hline Time: & & 0.04 & 0.02 & 0.01 & 0.01 \\
\hline
\end{tabular}

Table 4. Mean durations of tail positions of Kangal puppies in OFT.

Tablo 4. Açık alan testindeki Kangal yavrularının sergilediği kuyruk pozisyonlarının ortalama sergilenme süreleri.

\begin{tabular}{lcccc}
\hline $\begin{array}{c}\text { Dogs } \\
(\mathrm{n}=40)\end{array}$ & Weeks & $\begin{array}{c}\text { Tail normal } \\
\bar{x} \pm S \bar{x}\end{array}$ & $\begin{array}{c}\text { Tail low } \\
\bar{x} \pm S \bar{x}\end{array}$ & $\begin{array}{c}\text { Tail between legs } \\
\bar{x} \pm S \bar{x}\end{array}$ \\
\hline & 1 & $1.06 \pm 0.32^{\mathrm{a}}$ & $239.13 \pm 0.31^{\mathrm{a}}$ & $0.00 \pm 0.00$ \\
& 2 & $140.73 \pm 13.42^{\mathrm{b}}$ & $47.33 \pm 11.50^{\mathrm{b}}$ & $5.59 \pm 4.10$ \\
& 3 & $148.12 \pm 10.26^{\mathrm{b}}$ & $17.11 \pm 7.96^{\mathrm{bc}}$ & $1.72 \pm 2.26$ \\
& 4 & $154.63 \pm 11.22^{\mathrm{bc}}$ & $27.41 \pm 8.84^{\mathrm{bc}}$ & $1.08 \pm 1.0$ \\
& 5 & $161.57 \pm 11.55^{\mathrm{bc}}$ & $22.78 \pm 7.72^{\mathrm{bc}}$ & $0.00 \pm 0.00$ \\
$P$ values & 6 & $184.37 \pm 11.81^{\mathrm{c}}$ & $20.10 \pm 7.66^{\mathrm{c}}$ & \\
Main effect & & & & 0.76 \\
Time: & & 0.02 & 0.01 & 0.90 \\
\hline
\end{tabular}


$19.45 \pm 0.25$ days from birth. All puppies gave startle response to auditory stimuli when they were 3 weeks old.

Measurements during the OFT: Behaviors expressed before and after the activation of novel object were recorded separately. Accordingly, OFT was divided into 2 periods, i.e. the 1 st period of OFT and the 2 nd period of OFT. The behaviors observed in the 1st period of the OFT were evaluated as reactions of puppies to OFT situation, whereas behaviors observed in the 2nd period of the OFT were assessed as reactions to novel object.

Activity scores: The 1st period of OFT: The longest durations of thigmotactic behaviors (circling around test area) were detected in the $1 \mathrm{st}$ week $(24.75 \pm 7.62 \mathrm{sec})$. Unsteady walking was only observed in the 1 st test week $(72.88 \pm 8.18 \mathrm{sec})$. Durations of unsteady walking in female puppies were significanly longer than in male puppies $(\mathrm{p}<0.05)$.

Duration of standing significantly increased in the 2nd test week $(\mathrm{p}<0.05)$ (Table 3). Running and play-bow were first displayed by the puppies in the 2 nd week. Durations of escape intents significantly increased across test weeks $(\mathrm{p}<0.05)$ (Table 3$)$. Frequency of line crossing significantly decreased across test weeks $(p<0.05)$. Frequency of circling behavior showed significant differences between males $(2.77 \pm 0.05)$ and females $(1.68 \pm 0.14)(\mathrm{p}<0.05)$.

Sum of durations of standing, sitting, lying and freezing behaviors were recorded as durations of passive behaviors. Duration of lying significantly decreased at the 2 nd test week $(p<0.05)$. At the 3 rd test week, total durations of passive behaviors significantly increased $(\mathrm{p}<0.05)$ (Table 3).

The 2nd period of OFT: Sum of durations of activity levels increased between 2 nd to 4 th test weeks while it started to decrease as of the 4th week of OFT. Sum of durations of escape intents significanty decreased in the 4 th week $(p<0.05)$. Sum of durations of passive behaviors significantly increased in the 6th test week $(\mathrm{p}<0.05)$.

Exploratory behaviors: Sum of durations of walking and exploring floors, resting and exploring floors, walking and exploring walls, resting and exploring walls, passive exploration of novel object and active exploration of novel object were recorded as exploratory behaviors. Exploratory behaviors were displayed by puppies as of the 1st test week. Signifant decrease in duration of exploratory behaviors was observed in the $1 \mathrm{st}$ period of the OFT in the $3 \mathrm{rd}$ week as well as in the 2 nd period of OFT in the 4th week $(\mathrm{p}<0.05)$.

Vocalisations: It was detected that female puppies $(80.32 \pm 8.46 \mathrm{sec})$ vocalize more often than male puppies $(54.13 \pm 7.20 \mathrm{sec})$. Crying was the predominant vocalization across the first 5 test weeks. Barking and yelping were first detected in the 2nd week. Yelping was the predominant vocalisation at the last week.

Other behaviors: Body trembling was first detected in the 1st week and head trembling was first detected in the 3rd week. Body trembling and yawning were displayed at the highest frequency in the 3rd week. Mouth licking, polipne and paw lifting reached their highest frequencies in the 5th week. Eliminative behaviors were only detected in the 1 st period of the OFT across test weeks. Time spent for elimination significantly increased in the 2 nd test week.

Body language and temperament: Body expressions such as lowering ears, lowering tail, directing ears to the stimuli were first detected in the 2nd week. Sum of durations of normal tail position significantly increased in the 2nd test week $(\mathrm{p}<0.05)$ (Table 4). Self confident body posture, i.e. normal head, ear and tail position was dominant in Kangal puppies in repeated OFT exposures.

Barrier test: In total, 36 dogs $(90 \%)$ showed success in the barrier test. Puppies started to show success in the 3rd test week $(n=9 ; 25 \%)$. Most of the puppies $(\mathrm{n}=11 ; 31 \%)$ showed success in the 5 th test week.

Correlations: Positive correlations were found between opening of eyes and standing ( $\rho=0.68$; $\mathrm{p}<0.001)$. Barrier test success was found to have a positive correlation with opening of eyes $(\rho=0.33$; $\mathrm{p}<0.05)$.

\section{Discussion and Conclusion}

Measurements during the first 3 weeks after the birth: In the current literature, the first balanced standing for dog puppies is reported as 12-14 days after the birth $(17,19)$. In the present study, however, mean age of the first balanced standing was detected as 19 days in Kangal puppies. Different studies reported that large breeds tend to develop motor abilities later than small breeds in different species $(17,22,29)$. Accordingly, it can be suggested that Kangal puppies which belong to giant breed puppies develop motor abilities more slowly than normal breeds. However, there is still lack of comparable data for development of early motor abilities in dog breeds of different sizes. Thus, future studies should be conducted in order to investigate development of motor abilities in different dog breeds. In this study, it was also shown that puppies stand earlier in case that their eyes open earlier. This finding supports the hypothesis that vision is important on improving motor abilities in dog puppies (17).

Measurements during the OFT: Different authors stated that thigmotactic behaviors may reflect high emotional reactivity in animals and, further that in case of high emotional reactivity, animals tend to spend more time close to the OFT walls $(6,20)$. In this study, longest 
durations of circling around test area and wall-seeking behaviors were detected in the 1st test week. Explorative behaviors were displayed by Kangal puppies as of the 1st test week. Thus, it can be suggested that puppies were able to react to the OFT at 3 weeks old age which supports the hypothesis that myelinisation in thalamocortical way in dog puppies completed at 3-4 weeks old age (12). Since hippocampus and dorsal striatum are important for spatial organisation, lesions on those areas increase thigmotactic behaviors in animals (9). Therefore, limbic system development seems to link to lower thigmotactic behavior in repeated OFT exposures (22). In our study, it was also observed that circling around test area in the following weeks is more likely to be looking for a way of escape rather than true thigmotactic behavior which is accompanied with anxiety and fear.

In the present study, "shaky walking" (walking unsteadily) was only detected in the 1st test week. In the 2nd test week, time spent for walking significantly increased and running behavior appeared. Moreover, during the 2nd test week, time spent for lying significantly decreased whereas time spent for standing significantly increased. Marchei et al. (22) stated that the rise in activity and standing position in kittens across weeks might be linked to progressive maturation of corticospinal pathways. Accordingly, one may suggest that progressive myelinisation of corticospinal pathway results in rise in time spent for steady walking, standing and running in Kangal puppies in the 2nd OFT week. Significant sex differences were detected considering shaky walking. Mean time of shaky walking was significantly higher in females than those in males. Several studies showed that development of brain differs in boys and girls $(2,5)$. Moreover, a cross-sectional diffusion tensor imaging study which investigated development of white matter microstructure in children showed greater mean diffusivity in the corticospinal tract of boys in comparison to of girls (27). Thus, our finding may indicate that maturation of corticospinal tract differs in male and female puppies.

Sum of durations of passive behaviors significantly increased in the 3rd test week. One possible explanation could be habituation and emotional conditioning as a result of progressive development of hypothalamus (15, 22). Another explanation might be emergence of fear behaviors as a result of development of amygdala (32). However, since body languages of dog puppies were mostly evaluated as self-confident in the 3 rd test week, first hypothesis, i.e. habituation is the most likely.

During the first period of the OFT, activity level was measured above $50 \%$ as of 4 th week of the OFT. However, significant decrease in frequency of line crossing has been detected across weeks. Although these results seem to contradict each other, one possible explanation is that increase in escape attempts, i.e. scratching or climbing the wall/rearing with front paws on the wall is the main factor of increasement of activity level whereas it decreases the number of line crossing. Interestingly, it was observed that in the 2 nd period of OFT, escape intents decrease across weeks as of the 3rd weeks of repeated OFT exposures. This result may be explained by that puppies were able to associate novel object with the end of the test as a result of development of hipocampus and medial lob which associate with associative learning $(23,30)$. Thus, they learned to lower their activity and waited for the end of the test with the activity of novel object.

In this study, significant differences were found in durations of vocalisations and circling behaviors between male and female puppies. In general, female puppies displayed circling behavior and vocalisations more often than male puppies. Circling behavior in OFT situations can be classified as displacement behavior. Displacement behaviors are behaviors expressed by animals under acute stress in case of that they are not able to escape from or remove the source of stress $(7,13)$. Thus, one may suggest that female Kangal puppies are more sensitive to stress in comparison to male Kangal puppies as in humans (3). Another explanation might be that male and female Kangal puppies chose different coping strategies in case of stress.

It was observed that types of vocalisation have been changed across test weeks. In parallel with findings of Fredericson (14), yelping was the predominant stress vocalisation in 8 week old Kangal puppies in OFT.

In this study, it was detected that passive stress reactions such as head and body trembling as well as yawning were predominant reactions in the 3 rd test week whereas active stress related behaviors such as escape intents and vocalisations were predominant reactions in the 5th week in Kangal puppies. Different stress reactions in different weeks in Kangal puppies may be linked to pregressive development of cantral nervous system and behavior. Elimination peak was observed in the 2 nd week of age. Since it was the time in which Kangal puppies started to display fear related body postures, one may assume that stress related body postures and behaviors started to appear as a result of progressive development of amygdala in 4 weeks old Kangal puppies (10).

Body posture and breed specific characteristics: In the present study, escape attempts of the puppies significantly increased along test weeks. Moreover, percentage of activity time over the first period of OFT was above $50 \%$. Body postures of the puppies were detected as self-confident and attendant, in general. Considering above mentioned results, Kangal puppies 
might be classified as bold and active puppies according to "Shyness-Boldness" axis (18).

Since Kangal puppies started to display fear related body posture in the 2 nd test week, one may suggest that it is possible to evaluate emotional body expression in 4 weeks old Kangal puppies.

Barrier test: Although Scott and Fuller (29) stated that 6 weeks old age was the earliest age of problem solving behavior in dog puppies, 5 weeks old Kangal puppies started to show success in the barrier test. Since in this week escape behavior significantly decreased in the 2nd part of OFT, this outcome also might show that progressive developments of brain parts associated with associative learning and problem solving in 5 weeks old Kangal puppies.

Findings of this study showed that 4 weeks of age is important for development of fine motor abilities such as steady walking and running in Kangal puppies. Five weeks of age, on the other hand, was determined as significant period for development of emotional memory (amygdala), habituation (hypocampus), learning and problem solving (amygdala, medial lob and prefrontal cortex). In general, characteristics of Kangal puppies can be classified as "bold" according to "shyness-boldness axis".

As a result, this study demonstrated that although development of motor and phsiological abilities is seemly slow during the first 3 weeks after birth in Kangal puppies, behavioral development is considerably faster in the following weeks.

\section{References}

1. Altmann J (1974): Observational study of behaviour: sampling methods. Behaviour. 49, 227-267.

2. Blanton RE, Levitt JG, Peterson JR, et al. (2004): Gender differences in the left inferior frontal gyrus in normal children. Neuroimage, 22, 626-636.

3. Cahill L (2005): His brain, her brain. Sci. Am. 295, 4047.

4. Campbella T, Lina S, DeVriesb C, et al. (2003): Coping strategies in male and female rats exposed to multiple stressors. Physiol Behav 78, 495-504.

5. Caviness VS, Kennedy DN, Richelme C, et al. (1996): The human brain age 7-11 years: a volumetric analysis based on magnetic resonance images. Cereb. Cortex. 6,726-736.

6. Clément Y, Chapouthier G (1998): Biological bases of anxiety. Neurosci Biobehav Rev 22, 623-633.

7. Dantzer R, Mormede P (1985): Stress in domestic animals: A psychoendocrine approach. In: Moberg, G. P. (Ed), Animal Stress, American Physiological Society, Maryland.

8. Dehasse J (1994): Sensory, emotional and social development of the young dog. Bulletin for Veterinary Clinical Ethology, 2, 6-29.

9. Devan BD, Goad EH, Petri HL (1996): Dissociation of hippocampal and striatal contributions to spatial navigation in the water maze. Neurobiol Learn Mem, 66 , 305-323.

10. Forster G, Novick A, Scholl J, et al. (2012): The Role of the Amygdala in Anxiety Disorders. In: Ferry, B (Ed), The Amygdala - A Discrete Multitasking Manager.

11. Fox MW (1971): Integrative development of brain and behavior in the dog. Chicago, IL: University of Chicago Press.

12. Fox MW (1978): The Dog: Its Domestication and Behaviour. Garland, S \& P.M. Press, New York.

13. Friend TH (1991): Symposium: Response of animal to stress. J Dairy Sci, 74, 292-303.

14. Fredericson E (1952): Perceptual homeostasis and distress vocalizations in puppies. J Pers 20, 472-477.

15. Frederickson CJ, Frederickson MH (1979): Developmental changes in open field behavior in the kitten. Dev. Psychobiol. 12, 623-628

16. Grandin T, Deesing MJ (1998): Genetics and animal welfare. In: Grandin T (ed) Genetics and the behavior of domestic animals. Academic Press, San Diego, California, pp. 319-346.

17. Houpt KA (2005): Domestic animal behavior. Blackwell publishing limited.

18. Koolhaas JM, De Boer SF, Coppens CM, et al. (2010): Neuroendocrinology of coping styles: Towards understanding the biology of individual variation. Front. Neuroendocrin, 31, 307-321.

19. Lindsay SR (2000): Handbook of applied dog behavior and training: Volume one. Adaptation and Learning. Iowa State University Press, Ames.

20. Lipkind D, Sakov A, Kafkafi N, et al. (2004): New replicable anxiety-related measures of wall vs. center behavior of mice in the open field. J Appl Physiol, 97, 347359.

21. Manteca X, Deag JM (1993): Individual differences in temperament of domestic animals: a review of methodology. Anim Welf, 1, 247-68.

22. Marchei P. Diverio S, Falocci N, et al. (2009): Breed differences in behavioural development in kittens. Physiol Behav, 96, 522-531.

23. Mayes A, Montaldi D, Migo E (2007): Associative memory and the medial temporal lobes. Trends Cogn Sci, 11, 126-135.

24. Overall K (2013): Clinical behavioral medicine for small animals. Mosby, St. Louis.

25. Pfaffenberger C (1963): The new knowledge of dog behavior. New York, Howel Book House pp.159.

26. Reenen CG van, Engel B, Heutinck LFM, et al. (2004): Behavioural reactivity of heifer calves in potentially alarming test situations: a multivariate and correlational analysis. Appl Anim Behav Sci, 85, 11-30.

27. Schmithorst VJ, Holland SK, Dardzinski BJ (2008): Developmental differences in white matter architecture between boys and girls. Hum Brai Mapp, 29, 696-710.

28. Schoon A, Berntsen T.G (2011): Evaluating the effect of early neurological stimulation on the development and training of mine detection dogs. J Vet Behav, 6, 150-157.

29. Scott JP, Fuller JL (1965): Dog Behavior: The Genetic Basics. University Chicago Press, Chicago, IL.

30. Stark CEL, Squire LR (2003): Hippocampal damage equally impairs memory for single items and memory for conjunctions. Hippocampus, 13, 281-292. 
31. Svartberg K, Forkman B (2002): Personality traits in domestic dog (Canis familiaris). Appl Anim Behav Sci, 79, 133-155.

32. Vargas JP, Lopez JC, Portavella M (2012): Amygdala and emotional learning in vertebrates- A comparative perspective. In: Ferry, B. (Ed), The Amygdala - A Discrete Multitasking Manager.

33. Walsh RN, Cummins RA (1976): The open field test: A critical review. Psychological Bulletin, 83, 482-504.
34. Wilsson E, Sundgren PE (1998): Behaviour test for eightweek old puppies-heritabilities of tested behaviour traits and its correspondence to later behaviour. Appl Anim Behav Sci, 58, 151-162.

Geliş tarihi: 12.06.2015 / Kabul tarihi: 12.10.2015

Address for correspondence:

Dr. Yasemin Salgırlı Demirbaş

Ankara Üniversitesi, Veteriner Fakültesi

Fizyoloji Anabilim Dalı, 06110 Dışkapı Ankara

e-posta: salgirli@veterinary.ankara.edu.tr 